\title{
Pengendalian Hama Semut Hitam pada Pohon Rambutan Parakan dengan Memanfaatkan Ampas Kopi
}

\author{
Sultana, Notarianto, dan Ayu Vandira Candra Kusuma \\ Program Studi Agroteknologi Fakultas Pertanian Universitas Respati Indonesia Jakarta \\ Email: sultan.dramendra105@gmail.com
}

\begin{abstract}
ABSTRAK
Hama dan penyakit pada tanaman merupakan salah kendala yang cukup rumit dalam usaha pertanian. Keberadaan hama dan penyakit merupakan faktor yang menghambat pertumbuhan tanaman dan pembentukan hasil. Rambutan merupakan tanaman buah tropis dari Indonesia, buah rambutan mempunyai gizi, zat tepung, sejenis gula yang terlarut dalam air, zat protein, dan asam amino. Rambutan varietas parakan merupakan tumbuhan endemis khas Tangerang. Rambutan ini memiliki buah berwarna putih, kenyal, dan manis. Limbah ampas kopi pada umumnya dibuang dan menjadi limbah rumah tangga, padahal pengalaman di lapangan limbah ampas kopi bisa dimanfaatkan sebagai pestisida untuk mengendalikan hama dan penyakit tanaman, karena mempunyai kandungan nitrogen, fosfor, kalium dan $\mathrm{pH}$ yang rendah. Penelitian ini bertujuan untuk mengendalikan hama semut hitam pada pohon rambutan varietas parakan dengan menggunakan limbah rumah tangga yaitu ampas kopi. Penelitian ini dilaksanakan di Ciputat Tangerang Selatan pada bulan Februari sampai dengan Agustus 2021. Rancangan yang digunakan yaitu Rancangan Acak Lengkap dengan ampas kopi yang terdiri atas 5 perlakuan yaitu T1 (Kepekatan 15\%), T2 (Kepekatan 25\%), T3 (Kepekatan 50\%), T4 (Kepekatan 75\%), dan T5 (Kepekatan 85\%) diulang 4 kali, setiap perlakuan diberi 10 ekor semut hitam. Parameter yang diamati adalah jumlah semut yang tidak naik ke ranting selama satu jam. Hasil penelitian menunjukkan bahwa perlakuan perbedaan kepekatan ampas kopi berpengaruh terhadap tingkah laku semut hitam. Ampas kopi mempengaruhi jumlah semut hitam yang naik ke ranting pohon rambutan parakan. Persentase semut yang tidak naik ke ranting perlakuan kepekatan $75 \%$ memberikan hasil terbaik yaitu $45.50 \%$ semut yang tidak naik ke ranting.
\end{abstract}

Kata Kunci: Perlindungan Ampas Kopi, Rambutan Varietas Parakan, Semut Hitam

\section{ABSTRACT}

Pests and diseases in plants are one of the most complicated problems in agriculture. The presence of pests and diseases is a factor that inhibits plant growth and yield formation. Rambutan is a tropical fruit plant from Indonesia, rambutan fruit has nutrients, starch, a type of sugar dissolved in water, protein substances, and amino acids. The Parakan variety rambutan is an endemic plant typical of Tangerang. This rambutan has white, chewy, and sweet fruit. Coffee grounds are generally disposed of and become household waste, whereas in the field experience coffee grounds can be used as pesticides to control pests and plant diseases, because they contain nitrogen, phosphorus, potassium and low $\mathrm{pH}$. This study aims to control black ant pests on rambutan trees of the Parakan variety by using household waste, namely coffee grounds. This research was conducted in Ciputat, South Tangerang from February to August 2021. The design used was a completely randomized design with coffee grounds consisting of 5 treatments, namely T1 ( $15 \%$ concentration), T2 ( $25 \%$ concentration), T3 (50\% concentration). ), T4 (75\% concentration), and T5 (85\% concentration) were repeated 4 times, each treatment was given 10 black ants. The parameter observed was the number of ants that did not climb onto the branches for one hour. The results showed that the treatment of differences in the concentration of coffee grounds had an effect on the behavior of black ants. Coffee grounds affect the number of black ants that climb onto the branches of the parakan rambutan tree. The percentage of ants that did 
not climb onto the twigs at $75 \%$ concentration gave the best results, namely $45.50 \%$ of ants that did not climb onto the twigs.

Keywords: Protection of Coffee Grounds, Rambutan of Parakan Variety, Black Ants

\section{PENDAHULUAN}

Gangguan hama dan penyakit pada tanaman merupakan salah satu kendala yang cukup rumit dalam usaha pertanian. Keberadaan hama dan penyakit merupakan faktor yang dapat menghambat pertumbuhan tanaman dan pembentukan hasil. Serangannya pada tanaman dapat datang secara mendadak dan dapat bersifat eksplosif sehingga dalam waktu yang relatif singkat seringkali dapat mematikan seluruh tanaman dan menggagalkan panen.

Pemberantasan hama dan penyakit secara total tidak mungkin dapat dilakukan karena perkembangannya yang sangat cepat dan sulit dikontrol. Namun dengan pengamatan yang baik di lapangan sejak awal penanaman sampai panen, serangan hama dan penyakit dapat ditekan.

Semut (Hymenoptera : Formicidae) merupakan serangga yang ditemukan pada hampir setiap jenis ekosistem kecuali di daerah kutub dan memiliki beragam peran dalam ekosistem dan sangat melimpah di kepulauan maupun daratan yang luas diperkirakan mencapai 15.000 species. Semut memiliki habitat yang bervariasi, mulai dari padang pasir, savana, hutan hujan tropis, sampai area yang sudah dihuni oleh manusia [1]. Semut mempunyai peranan penting di alam ini, namun peran itu ada yang bersifat positif dan ada yang bersifat negatif. Peranan semut di alam juga tidak langsung dirasakan oleh manusia, namun untuk keberlanjutannya sangat bermanfaat sekali. Manfaat positif dari peran semut adalah sebagai predator, menguraikan bahan organik, membantu proses penyerbukan dan membantu proses dekomposisi serasah. Peran negatif semut biasanya pada saat panen bisa merusak hasil panen terutama untuk tanaman buah dan sayuran.

Semut biasanya keluar dari sarangnya pada waktu pagi dan sore hari ketika suhu tidak terlalu panas. Semut akan menuju pucuk-pucuk tanaman untuk mendapatkan cahaya matahari sambil menjalankan aktivitasnya. Akan tetapi pada siang hari ketika suhu udara panas, semut akan bersembunyi pada tempat-tempat yang terlindungi dari sengatan sinar matahari secara langsung, seperti di dalam sarang, di balik dedaunan, di tanah [2]. Semut memiliki habitat yang bervariasi, mulai dari padang pasir, savanna, hutan hujan tropis, sampai pada area yang telah dihuni oleh manusia. Keberadaannya yang melimpah di alam tidak lepas dari pengaruh ketersediannya makanan dan kesesuaianya 
dengan kondisi lingkungan. Semut merupakam fauna yang dominan di sebagaian besar ekosistem darat [3].

Rambutan (Nephelium lappaceum)

merupakan tanaman buah holtikuktura berupa pohon dengan famili Sapindancaeae.Tanaman buah tropis ini dalam bahasa Inggrisnya disebut Hair Fruit berasal dari Indonesia. Hingga saat ini telah menyebar luas di daerah yang beriklim tropis seperti Filipina dan negara-negara Amerika latin dan ditemukan pula di daratan yang mempunyai iklim sub-tropis melalui penyebaran alamiah salah satunya dengan menggunakan biji buah rambutan. Rambutan merupakan salah satu buah yang mengandung zat-zat yang diperlukan oleh tubuh manusia. Tanaman buah rambutan sengaja dibudidayakan untuk dimanfaatkan buahnya yang mempunyai gizi, zat tepung, sejenis gula yang mudah terlarut dalam air, zat protein dan asam amino, zat lemak, zat enzim-enzim yang esensial dan non esensial, vitamin dan zat mineral makro serta mikro yang menyehatkan keluarga, tetapi ada pula masyarakat yang memanfaatkannya sebagai pohon pelindung di pekarangan sebagai tanaman hias.

Rambutan parakan yang manis, berbuah padar, serta sedikit air ini semakin sulit dicari, bahkan di kawasan penghasil rambutan itu sendiri yakni didaerah Pengadengan, Legok, Rumpin, kabupaten Tangerang sekalipun sudah sangat sedikit dikarnakan pengembang-pengembang perumahan elit melebarkan sayapnya menyebabkan semakin sulitnya untuk mengembangkan penanaman pohon rambutan parakan. Masih terdapat beberapa pekarangan warga yang di tanami pohon rambutan tetapi terkendala hama penyakit semut hitam yang menyebabkan buah rambutan busuk saat matang fisiologis. Kesulitan petani memperoleh atraktan dari bahan buatan pada saat dibutuhkan perlu diatasi dengan mencari atraktan dari bahan-bahan alami lokal sebagai pengganti atraktan dari bahanbahan buatan. Mengingat kesulitan tersebut, maka perlu dicari atraktan alternatif yang berasal dari bahan-bahan nabati alami yang ada disekitar petani. Bahan-bahan nabati alami ramah lingkungan tersebut diharapkan dapat berfungsi sebagai atraktan pada perangkap hama serangga. Solusi pengendalian semut hitam secara ramah lingkungan salah satunya dapat dilakukan dengan ampas kopi yang merupakan limbah rumah tangga.

Banyak orang yang gemar meminum kopi, namun banyak yang tidak mengetahu bahwa ampas kopi dapat dimanfaatkan sebagai pupuk tanaman dan mengusir serangga seperti semut. Pertambahan jumlah penduduk di DKI Jakarta dan perubahan pola konsumsi dan gaya hidup masyarakat telah meningkatkan jumlah timbunan sampah rumah tangga yang 
semakin hari semakin meningkat khususnya dalam hal ini limbah rumah tangga ampas kopi. Limbah ampas kopi pada umumnya dibuang dan menjadi limbah rumah tangga, padahal bedasarkan limbah ampas kopi bisa dimanfaatkan sebagai pestisida untuk mengendalikan hama penyakit tanaman karna mempunyai kandungan nitrogen, fosfor, kalium dan $\mathrm{pH}$ yang rendah. Tujuan penelitian adalah mengetahui pengaruh ampas kopi terhadap semut hitam yang menyerang tanaman rambutan parakan.

\section{METODE}

\section{Waktu dan Tempat}

Penelitian dilaksanakan di Ciputat Kota Tangerang Selatan pada Februari sampai Agustus 2021.

\section{Alat dan Bahan}

Alat-alat yang digunakan pada penelitian adalah aquarium yang telah disekat, tally counter, kaca pembesar, hygrometer, termometer, atmometer gelas ukur, timbangan analitik, pooter. Bahanbahan yang digunakan dalam penelitian adalah: semut hitam, ranting rambutan, ampas kopi, cairan buah rambutan.

\section{Rancangan Penelitian}

Rancangan yang digunakan yaitu Rancangan Acak Lengkap dengan ampas kopi yang terdiri atas 5 perlakuan, yaitu T1 (Kepekatan 15\%), T2 (Kepekatan 25\%), T3
(Kepekatan 50\%), T4

(Kepekatan 75\%), dan T5 (Kepekatan 85\%) diulang 4 kali, sehingga diperoleh 20 satuan percobaan. Setiap perlakuan diberi 10 ekor semut hitam.

\section{Prosedur Penelitian}

Semut yang digunakan dalam penelitian ini adalah semut hitam yang biasa menjadi hama pohon rambutan. Pengumpulan semut dilakukan pada pagi hari dengan menggunakan alat potter untuk menghindari terjadinya semut mati sebelum dilakukan percobaan. Ranting rambutan yang digunakan adalah ranting yang mendekati buah saat dipotong dengan ukuran $12 \mathrm{~cm}$. Ranting rambutan kemudian diolesi dengan ampas kopi dan glukosa rambutan untuk merangsang semut agar naik ke atas. Pengaturan iklim mikro bertujuan agar udara di luar dan di dalam ruangan percobaan berada pada iklim mikro yang sama.

Pengaturan iklim mikro dilakukan menggunakan kipas angin atau blower, hygrometer untuk mengukur kelembaban udara dan atmometer untuk mengukur penguapan udara. Terrarium yang telah diisi ranting rambutan dan masing-masing ranting yang telah dioleskan glukosa rambutan, tiap ranting rambutan yang telah diberi ampas kopi yang berbeda-beda kepekatan ampas kopinya. Masing-masing 
terrarium mini diisi 10 ekor semut hitam (semut hitam pekerja).

\section{Variabel Penelitian}

Variabel penelitian adalah Jumlah semut dalam terarium yang tidak naik melewati ampas kopi pada ranting rambutan di pagi hari pada jam 8 sampai jam 10 pagi dan jumlah semut dalam terarium yang tidak naik melewati ampas kopi pada ranting rambutan di malam hari pada jam 8 sampai jam 10 malam.

\section{Analisis Data}

Data hasil pengamatan diuji dengan analisa sidik ragam, bila hasil sidik ragam berbeda nyata ( $F$ hitung $>F$ tabel 0,05 ) atau berbeda sangat nyata ( $F$ hitung $>F$ tabel 0,01), maka untuk membandingkan dua rata-rata taraf perlakuan, dilakukan uji lanjutan dengan uji $t$ taraf $5 \%$ sedangkan bila sidik ragam berbeda tidak nyata ( $F$ hitung $\leq \mathrm{F}$ tabel 0,05 ), maka tidak dilakukan uji lanjutan. Analis data menggunakan program SPSS.

\section{HASIL DAN PEMBAHASAN}

\section{Gambaran Umum Wilayah}

Lokasi penelitian berada di Kota Tangerang selatan berada $30 \mathrm{KM}$ di sebelah Jakarta. Tangerang selatan merupakan wilayah yang berada pada dataran rendah dengan kemiringan 0-3\% dengan topografi datar mempunyai jenis latosol dengan $\mathrm{pH}$ 6-
7. Kecamatan Ciputat terletak di kota Tangerang selatan dengan temperatur udara rata-rata berkisar antara $23,74-32,68^{\circ} \mathrm{C}$ dengan temperatur tertinggi pada bulan September $34,50^{\circ} \mathrm{C}$ dan temperatur rendah pada bulan Febuari yaitu $22,90^{\circ} \mathrm{C}$, kelembaban udara dan intensitas matahari sekitar $79 \%$ dan 53,8\% rata-rata hujan dalam setahun $166,7 \mathrm{~mm}$ per tahun.

\section{Pengaruh Ampas Kopi terhadap Semut \\ Hitam Pada Pengamatan Pagi Hari}

Pengamatan semut yang tidak naik pada pagi hari dilakukan selama 2 hari selama 2 jam dan diulang selama 4 kali. Data hasil pengamatan kemudian dianalisi menggunakan uji One Way Anova tingkat signifikan perlakuan ampas kopi yang disajikan pada Tabel 1.

Kafein merupakan senyawa xantina yang memiliki bentuk kristal dan mempunyai rasa pahit yang bekerja sebagai obat diuretik ringan dan perangsang psikokoaktif [4]. Kafein termasuk senyawa sejenis alkaloid heterosiklik dalam golongan methyxanthine, yang merupakan senyawa organik mengandung nitrogen yang memiliki sruktur dua cincin. Molekul ini secara alami terjadi dalam banyak jenis tanaman sebagai metabolik sekunder. Fungsinya dalam tumbuhan sebagai pestisida alami yang dapat melumpuhkan dan membunuh serangga yang memakan tumbuhan tersebut. 
Dari hasil pengamatan ini semut lebih banyak mencari makan di pagi hari. Semut akan keluar dari sarangnya pada waktu pagi dan sore ketika suhu tidak terlalu panas. Kafein banyak mengeluarkan zat karbon yang bisa menganggu pernapasan pada semut, sehingga semut sulit untuk bernafas [5].

Tabel 1. Anova Semut yang Tidak Naik pada Pagi Hari

\begin{tabular}{|c|c|c|c|c|c|}
\hline ANOVA & & & & & \\
\hline Semut yang Tidak & Vaik Pagi & & & & \\
\hline & Sum of Squares & $\mathrm{df}$ & Mean Square & $\mathrm{F}$ & Sig. \\
\hline Between Groups & 3885.700 & 4 & 971.425 & 167.007 & .000 \\
\hline Within Groups & 87.250 & 15 & 5.817 & & \\
\hline Total & 3972.950 & 19 & & & \\
\hline
\end{tabular}

Pada hasil uji Anova di atas dapat dilihat bahwa nilai signifikasi lebih kecil dari 0,05 yaitu 0,00 sehingga $\mathrm{HO}$ ditolak dengan kesimpulan perlakuan treatment ampas kopi memberikan pengaruh yang signifikan terhadap semut hitam. Perlakuan signifikan maka dilakukan Uji lanjut menggunakan Uji Duncan dengan hasil disajikan pada Tabel 2.

Tabel 2. Uji BNT 5\% Pengamatan Pagi Hari

\begin{tabular}{|c|c|c|c|c|c|c|}
\hline \multicolumn{7}{|c|}{ Semut yang Tidak Naik Pagi } \\
\hline \multicolumn{7}{|l|}{ Duncan } \\
\hline \multicolumn{7}{|c|}{ Subset for alpha $=0.05$} \\
\hline Treatment & $\mathrm{N}$ & 1 & 2 & 3 & 4 & 5 \\
\hline $15 \%$ & 4 & $20.25 a$ & & & & \\
\hline $25 \%$ & 4 & & 25.00 & & & \\
\hline $50 \%$ & 4 & & & $35.75 a$ & & \\
\hline $75 \%$ & 4 & & & & $45.50 \mathrm{ab}$ & \\
\hline $85 \%$ & 4 & & & & & $58.75 a b$ \\
\hline Sig. & & 1.000 & 1.000 & 1.000 & 1.000 & 1.000 \\
\hline
\end{tabular}

Means for groups in homogeneous subsets are displayed. 
Keterangan : Angka-angka yang diikuti oleh hurup yang sama menunjukan tidak berbeda nyata pada uji BNT 5\%

Di dalam biji kopi terkandung beberapa senyawa kimia antara lain, kafein, trigoneline, protein, karbohidrat, asam alifatik, asam klorogenat, lemak, glikosida, mineral, dan komponen volatile [6]. Asam klorogenat selain bertindak sebagai antioksidan pada manusia, juga bersifat menarik serangga [7]. Senyawa metabolit sekunder yang terdapat pada tanaman atau yang berasal dari tanaman akan mudah mengalami penguraian [8]. Di dalam biji kopi terkandung beberapa senyawa kimia antara lain, kafein, trigoneline, protein, karbohidrat, asam alifatik, asam klorogenat, lemak, glikosida, mineral, dan komponen volatile [9]. Asam klorogenat pada biji kopi sangat tinggi dan dapat mencapai 12 persen berdasarkan bobot [6]

Tabel 2 merupakan hasil uji Duncan perlakuan ampas kopi terhadap semut hitam terlihat ada korelasi antar perlakuan. Kemampuan gerak ganglion dan struktur nervus pherepher mengalami kelemahan bila kafein kadar tinggi di absorb melalui corong hawa membuat nalurianya menjauh dalam animal behavior. Semut termasuk kelas hexapoda artinya mempunyai 6 kaki, kaki bagian depan dinamakan extremitas anterior, kaki bagian tengah dinamakan extremitas abdominalis dan kaki belakang dinamakan extremitas fostorior.

$$
\text { Insting naluria semut bisa }
$$

membedakan siang, semut keluar dari sarangnya melalui antena juga bisa membedakan suhu panas dan suhu dingin, kecenderungan aktifitas di siang hari sehingga semut tergolong serangga yang aktifitasnya disiang hari (diurnal).

\section{Pengaruh Ampas Kopi terhadap Semut Hitam Pada Pengamatan Malam Hari \\ Pengamatan semut yang tidak naik pada malam hari dilakukan selama 2 hari selama 2 jam dan diulang selama 4 kali. Data hasil pengamatan kemudian dianalisi menggunakan uji One Way Anova tingkat signifikan treatment ampas kopi disajikan pada Tabel 3.}

Tabel 3. Anova Semut yang Tidak Naik pada Malam Hari

\section{ANOVA}

Semut yang Tidak Naik Malam

$$
\text { Sum of Squares }
$$

Df

Mean Square

F

Sig.

Between Groups

3749.300

4

$937.325 \quad 141.661$

.000 


$\begin{array}{lrcc}\text { Within Groups } & 99.250 & 15 & 6.617 \\ \text { Total } & 3848.550 & 19 & \end{array}$

Pada hasil uji Anova di atas dapat dilihat bahwa nilai signifikasi lebih kecil dari 0,05 yaitu 0,00 sehingga $\mathrm{HO}$ ditolak dengan kesimpulan perlakuan ampas kopi

Tabel 4. Uji BNT 5\% Pengamatan Malam Hari memberikan pengaruh yang signifikan terhadap semut hitam karena perlakuan signifikan maka dilakukan Uji lanjut menggunakan Uji Duncan seperti yang disajikan pada Tabel 4.

\section{Semut yangTidak Naik Malam}

Duncan

Subset for alpha $=0.05$

\begin{tabular}{|c|c|c|c|c|c|}
\hline Treatment & $\mathrm{N}$ & 1 & 2 & 3 & 4 \\
\hline $15 \%$ & 4 & $17.50 \mathrm{a}$ & & & \\
\hline $25 \%$ & 4 & $21.25 a$ & & & \\
\hline $50 \%$ & 4 & & $30.00 a$ & & \\
\hline $75 \%$ & 4 & & & $38.75 a b$ & \\
\hline $85 \%$ & 4 & & & & $55.75 a b$ \\
\hline Sig. & & .057 & 1.000 & 1.000 & 1.000 \\
\hline
\end{tabular}

Means for groups in homogeneous subsets are displayed.

Keterangan : Angka-angka yang diikuti oleh hurup yang sama menunjukkan tidak berbeda nyata pada uji BNT 5\%

Tabel 4 merupakan hasil uji Duncan perlakuan ampas kopi terhadap semut hitam terlihat ada korelasi antar perlakuan. Semakin rendah kepekatan ampas kopi yang gunakan, hanya sedikit menurunkan daya rangsang pada sistem reseptor antena dan ganglion, sehingga semut memungkinkan naik ke atas, kemampuan semut menembus kafein yang kadar rendah mampu melemahkan reflek-reflek ganglion yang menurunkan secretie yang mengandung feromon. Feromon yang berkadar rendah tidak mengundang koloni semut untuk mendekat, semakin tinggi kadar kafein 
semakin tinggi kadar carbon yang ada pada kafein menimbulkan hambatan gerak reflek insting dan naluria semut yang menciumnya, sehingga secara naluria dan insting semut yang berikutnya tidak mampu mendeteksi feromon semut yang pertama. Bahwa tingkat kepekatan ampas kopi berpengaruh kepada semut, semakin pekat ampas kopi, semut tidak dapat naik ke atas karena bisa merusak corong hawa semut yang langsung menuju ke ganglion semut.

\section{KESIMPULAN}

Ampas kopi mempengaruhi jumlah semut hitam yang naik ke ranting pohon rambutan parakan. Perlakuan kepekatan $75 \%$ memberikan hasil terbaik yaitu $45,50 \%$ semut tidak naik ke ranting.

\section{DAFTAR PUSTAKA}

Latumahina, F.S. 2011. Pengaruh Alih Fungsi Lahan Terhadap Keanekaragaman Semut Alam Hutan Lindung Gunung Nona Ambon. Jurnal Agroforestri, 6 (1): 18-22.

Wijaya, Y. S. 2007. Kolonisasi Semut Hitam (Dolichoderus Thoracicus Smith) pada Tanaman Kakao (Theobroma cacao L.) dengan Pemberian Pakan Alternatif. Skripsi. Jurusan Biologi. Fakultas Matematika dan IImu Pengetahuan
Alam. Universitas Sebelas Maret Surakarta. Hal. 11-18.

Rosnadi, A.F. 2019. Identifikasi Semut (Hymenoptera: Formicidae: Myrmicinae Pada Tiga Tipe Perumahan Yang Ada Di Bandar Lampung. Skripsi. UIN Raden Intan Lampung.

Maramis, R.K., Citraningtyas, G., dan Wehantouw, F. 2013, Analisis Kafein Dalam Kopi Bubuk di Kota Manado Menggunakan Spektrofotometri UV Vis, Program Studi Farmasi FMIPA, UNSRAT, Manado.

Elzinga, R.J. 1978. Fundamentals of Entomology. Departement of Entomology Kansa State University. New Delhi

Embriani. 2014. Asam Klorogenat Alternatif Atraktan Hama PBK. BBPPTP. Surabaya.

Renwick, J.A.A \& F.S. Chew. 1994. Oviposition Behavior In Lepidoptera. Annu. Rev. Entornot, 39: 377-400.

Morallo-Rejesus, B. $1986 . \quad$ Botanical Insecticides Againts Diamondback Moth. Proc. of the First Int. Workshop.

Laila, M. S. I, Nurariaty, A., dan Annie, P. S. 2011. Aplikasi Konsep Pengendalian Hama Terpadu untuk Pengendalian Hama Bubuk Buah Kopi (H. hampei). J. Fitome dika, 7 (3): 162-166. 